\section{UNIVERSITY REPRESENTATION IN THE HOUSE OF COMMONS}

$\mathrm{B}^{\mathrm{T}}$ $Y$ the terms of the Representation of the People Bill now before Parliament, it is proposed that parliamentary representation shall be limited solely to county and borough constituencies, each returning a single member ; and that residence shall be the qualification for the franchise, with the usual conditions that electors must be British subjects of full age and not subject to any legal incapacity to vote. Hence the university constituencies would be abolished.

For some generations, there has not been any kind of redistribution of seats in the House of Commons, much less of redistribution by way of destroying one kind of seat, without preliminary attempts to find the maximum agreement. On this occasion there has been a Speaker's Conference, which recommended, without a dissentient voice, the retention of the university seats. Although all the supporters of the single transferable vote agreed that it was not applicable to constituencies with less than three members, yet it was preserved for the twomember university seats precisely to make it plain that it was desired to give the second largest party among university voters every possible advantage. So recently as October 1947, the present Lord Cbancellor, when promising a Bill for electoral reform arising out of the recommendations of the Committee of Electoral Registration, the Speaker's Conference, and the Committee on Electoral Law Reform, proclaimed that if his questioner was familiar with all the proceedings in those Committees, he would be able to forecast precisely what the Bill was going to do. It is difficult to see how Speakers' Conferences can in future be as friendly and non-partisan as they have not unsuccessfully striven to be in the past, if now those parts of the last Conference's recommendation which seem electorally damaging to the present majority in the House of Commons are to be treated so cavalierly.

University constituencies have existed in Britain for about a dozen generations; there is a vague pre-history even older than that. For what antiquity is worth, therefore, they have a title to consideration. Of something the same nature is the argument that university parliamentary representatives are now all that is left to keep alive the old principle of representing corporations. It was the rural corporations which were counties, and the urban corporations which were boroughs, that were represented in the old House of Commons ; and to them James I added the 'learned corporations', that is, the universities.

Looking down the list of those who have represented, for example, the University of Cambridge, it is easy to pick out distinguished names. Very early, Cambridge elected Francis Bacon. John Coke, Thomas Eden, a couple of Cromwells, George Thurloe, George Monk followed within half a century; and in the next generation, Sir William Temple, Sir Isaac Newton, and others scarcely less memorable. In the eighteenth century, a very high proportion indeed of the Cambridge men were lawyers of the highest distinction.
Towards the end of that century, William Pitt long sat for the University, and after him there were Palmerston, Copley (Lord Lyndhurst), Speaker Manners-Sutton, and others who held high office as ministers or judges, or were men of eminence in more purely intellectual fields. The Oxford list also includes many distinguished names ; and the other universities represented in Parliament have, considering the relative lateness of their entry into the field, a scarcely less significant record of service in the House of Commons.

The arguments against university representation can be reduced to two only. One is that it produces members whom the objector dislikes on personal or political grounds. This argument could be valid only if it be agreed that the members elected have been such as the House of Commons would have been better without. The many distinguished men, and more recently women, who have entered Parliament as members for the universities provide sufficient answer to this; it can scarcely be questioned that the House of Commons would have been much the poorer without them.

The other argument used against university representation is that it interferes with strict arithmetical proportion between the House of Commons and the voting public. But does anyone take this principle seriously in these times? It is generally admitted that from the arithmetical point of view Scotland and Wales are properly over-represented, and should continue to be overrepresented, in virtue of their national and historical significance. (Incidentally, a similar argument might well save the City of London, which is also threatened with the loss of its representatives.) It is agreed also that the difficulty of representing remote and thinly populated districts is such that they ought to have more members than arithmetical justice would confer upon them; and accordingly, as the House of Commons is at present constituted, and as the Bill now before the House proposes to reconstitute it, there is variation of the number of constituents needed to return a member, in accordance with remoteness from London and with excessive area. Indeed, anyone who really thinks the purely arithmetical principle the necessary dominant in the question is almost driven to proportional representation, with large numbers of seats per constituency, say six or seven, and to annual parliaments, if not to the right of recall by electors.

University mombers hold less than 2 per cent of the seats in the House of Commons, and nobody suggests that they should hold more. In the two- and three-member university seats, election is by a kind of proportional representation which gives special advantage to the second largest party. It is not reasonable to suggest that any great section of opinion need despair of carrying a university seat, unless it has a very remarkable faculty for antagoniz. ing university graduates. Indeed, there has been no attempt to organise university representation in a tightly partisan way. Any such attempt would almost certainly be doomed to defeat by opinion among 
graduates, and also, as already indicated, by the method of election in two- and three-member seats.

In any event, it cannot be a bad thing that there should be a few constituencies which are not local, in which the voters are scattered all over the country and indeed all over the world, and in which the rival candidates compete in long, reasoned statements rather than in slogans. The section of a university constituency resident overseas is a peculiarly important part of the nation. There is little doubt that a very high proportion of British subjects in important posts in Asia and Africa are university graduates. Very many of these men and women have no vote in other constituencies. A very high proportion indeed of them know their university member, or at least know the sort of man he is, and have friends who do know him directly. There is here a channel of communication between Westminster and Whitehall on one hand, and British subjects serving in public or private posts abroad on the other hand, which has a great and growing value.

The universities of Britain are the highest educational institutions of the country. It is not necessary to think their officers and representatives are overcomplacent about them; but they may fairly claim that the universities compare favourably, both in the quality of performance of their function and in public opinion about it, with other great institutions and productive agencies. Yet it is certain that the political and economic tendencies of the last two generations have made it far more difficult for universities and colleges to be independent and self-subsistent than they used to be, and far more difficult also for them to hope for re-endowment from any extra-governmental source. Incidentally, in connexion with Government gxants to the universities, it was as well, during the latter years of the War and in the period immediately following, that there should have been men in close touch not only with the leading figures at the universities, but also with Westminster and Whitehall, who preserved a critical faculty about blithe presumptions that in the immediately post-war period there would be, easily and of course, more and better education, with much more money and much more material at its disposal. Surely we are now at a moment when it is peculiarly evident that higher education, and especially the highest education, should have some guarantee of direct two-way communication between the universities and Westminster otherwise than by the relations between the official academic authorities and the Treasury and other Government departments, good and valuable though such relations are. The universities of Britain, as the culminating point of the educational system of the country and also as the symbols of a broad and cultured outlook on human affairs, are likely to increase in importance in the years to come. As such they are entitled to seats in the House of Commons, quite apart from the influence on the course of debate exerted by men of the type sent to Westminster by the universities. No satisfactory case can be made for the abolition of the university franchise.

\section{A SHORT HISTORY OF SCIENCE}

The Growth of Physical Science

By Sir James Jeans. Pp. $x+364+14$ plates. (Cambridge : At the University Press, 1947.) 12s. 6d. net.

7 HE reputation of Sir James Jeans as an interpreter of science for the educated layman stands deservedly high. His wide interests and broad sympathies, aided by an exceptional power of exposition and a lucid and dignified prose style, have won him a very considerable circle of readers; and his writings have done much to substantiate the claim that science, in spite of the technicalities with which it is necessarily surrounded, has a cultural value, and some right to be regarded as one of the 'humanities'. The strength of the reaction provoked by his books from the philosophers on one hand and from the upholders of the strictly utilitarian conception of science on the other may be taken as a measure of his achievement.

In "The Growth of Physical Science", his last volume, the proofs of which were revised by him just before his death in September 1946, Sir James Jeans breaks fresh ground. It is true that, in the last chapter, he brings us again to the frontiers of knowledge; but he is, in the main, concerned to trace the long and devious route by which the physical sciences have advanced to their present position. "I have thought," he writes in the preface, "I might usefully try to describe the main lines of advance of physical science, including astronomy and mathematics, but excluding all points and side-issues, in language nontechnical enough to be understood by readers who have no scientific attainments or knowledge." The last clause must not be taken too literally. It is, of course, scarcely possible to discuss the history and development of mathematics intelligently without the use of some mathematical symbols and processes. The reader, particularly in the earlier chapters, will find it necessary to evoke some memories of his school 'maths', and may, incidentally, find that subject glowing with an interest it had not awakened before. Nor can the reader "with no scientific attainments" be promised that he will understand every word of the highly condensed account of the era of modern physics contained in the last chapter. He may find himself confessing (like Alice after reading the immortal "Jabberwocky"), "Somehow it seems to fill my head with ideas-only I don't know exactly what they are". Even this degree of apprehension may be well worth while; it is, after all, with the history rather than the details of scientific discovery that the book is concerned.

It is no easy matter to compress within some three hundred and sixty pages the history of three great sciences; to do full justice to the genius of the ancients, facing absolutely new problems with nothing to guide them, and yet to give due space to the spate of discoveries and theories of modern times; to estimate the relative historical importance, say, of a Pythagoras and an Einstein, of Archimedes and Faraday. In the present volume roughly one third of the space is concerned with classical times, ending with the burning of the library at Alexandria; another third brings us to the end of the age of Newton; leaving some one hundred and thirty pages for the two hundred and fifty years since that date. One cannot help feeling that the pace, towards the end, is becoming a little breathless. No one but Jeans could have condensed so much into so small a space without reducing his text to a mere catalogue ; and 